\title{
Regional differentiation and the geopolitical and transboundary position of the Presheva Valley
}

\begin{abstract}
The determination of the Presheva Valley as a special region highlights the need for theoretical analysis and the use of different methods and principles which enable geographical regionalization. The Presheva Valley represents a natural continuation of the Albanian ethnic territories. With a very convenient position in terms of geography and transportation, as well as its geostrategic and geopolitical basis, it has been occupied by many invaders throughout different periods of history. Under the current administrative, political and territorial division of Serbia, the municipalities of Presheva and Bujanoci belong to the Pčinja district, based in Vranje, while the municipality of Medvegja belongs to the Jablanica district, based in Leskoc. The Presheva Valley has had the status of special region in various periods, but since it shares historical, ethnic and demographic characteristics with other Albanian ethnic territories, it has frequently been separated for the purpose of the assimilation of the Albanian people.
\end{abstract}

Keywords

Presheva Valley $\bullet$ geopolitical position • transboundary $\bullet$ floating channel - Corridor $X \cdot$ region

(c) University of Warsaw - Faculty of Geography and Regional Studies

\author{
Arsim Ejupi, Ibrahim Ramadani \\ Department of Geography, \\ Faculty of Mathematical and Natural Sciences \\ University of Prishtina, Kosovo \\ e-mail: arsim.ejupi@uni-pr.edu \\ e-mail: ibrahimramadani@yahoo.com \\ Received: 21 April 2016 \\ Accepted: 3 November 2016
}

Introduction

The Presheva Valley is located in the central part of the Balkan Peninsula - more precisely, between the Morava Valley in the north and the Vardar Valley in the south. These two valleys constitute the most important natural corridor connecting Europe with South East Europe, the Middle East and North Africa. The most important point in the Presheva Valley is the watershed that separates the catchment area of the Black Sea and the Aegean Sea. However, the low altitude of this watershed $(460 \mathrm{~m})$ 'unites' rather than 'separates'; therefore, it represents an important natural corridor, which is known as the 'Primary Axis of the Balkans'. As a result of the importance of this territory in transportation and strategic terms, the geopolitical position of the Presheva Valley is very complex and highly sensitive. Corridor $X$ is one of the most important transport corridors in South Eastern Europe and the shortcut to reach the Aegean Sea. Therefore, Serbia's efforts to maintain a privileged position in the geopolitical framework of the Balkans have been oriented towards the advantages offered by maintaining a central position on the Balkan Peninsula, with Corridor X crossing throughout its territory. The idea for building the Danube-Morava-Vardar floating channel confirms the continuation of Serbia's hegemonic aspirations on Albanian lands and shows the geostrategic importance of the Presheva Valley.

Principles of geographical regionalisation: A case study of the Presheva Valley

The determination of the Presheva Valley as a special region necessitates the theoretical analysis of the principles and methods used in the complex process of geographical regionalization. In the following section, we will give a general overview of these principles and methods, determining the common components that give the object of the study the role of a particular region.

Depending on the criteria used, there are numerous definitions relating to the region as a geographical category. This fact shows the complexity of designation and the need for a multidisciplinary approach to the study of regions as a geographical category and regionalism as a process. Different authors define the region as a homogeneous space of different size, varying according to selected natural-geographic, or social and economic, criteria. So, homogeneity is the main criteria involved in the process of the region's designation. As a result, a homogeneous region can be understood as a whole space consisting of several primary units with the same qualitative features, based on which it is distinguished from other sites (Pavlović and Šabić 2006). In all parts of a homogeneous region, there is a set of the same, most important, structural elements, as well as an intensity of their development and concentration. Another important feature of a region is uniformity resulting from a combination of natural and social elements. Furthermore, some authors define the region as a mental construction of regional consciousness and regional identity. The region core to geographical studies, especially social-geographic studies, and is the main principle of territorial adjustment. The pragmatism of this approach lies in the fact that the region represents a model for achieving the set of goals in the research framework.

Regionalization is an approach which is undertaken for the purpose of the recognition and spatial separation of homogeneous sites according to certain criteria. Every regional approach 


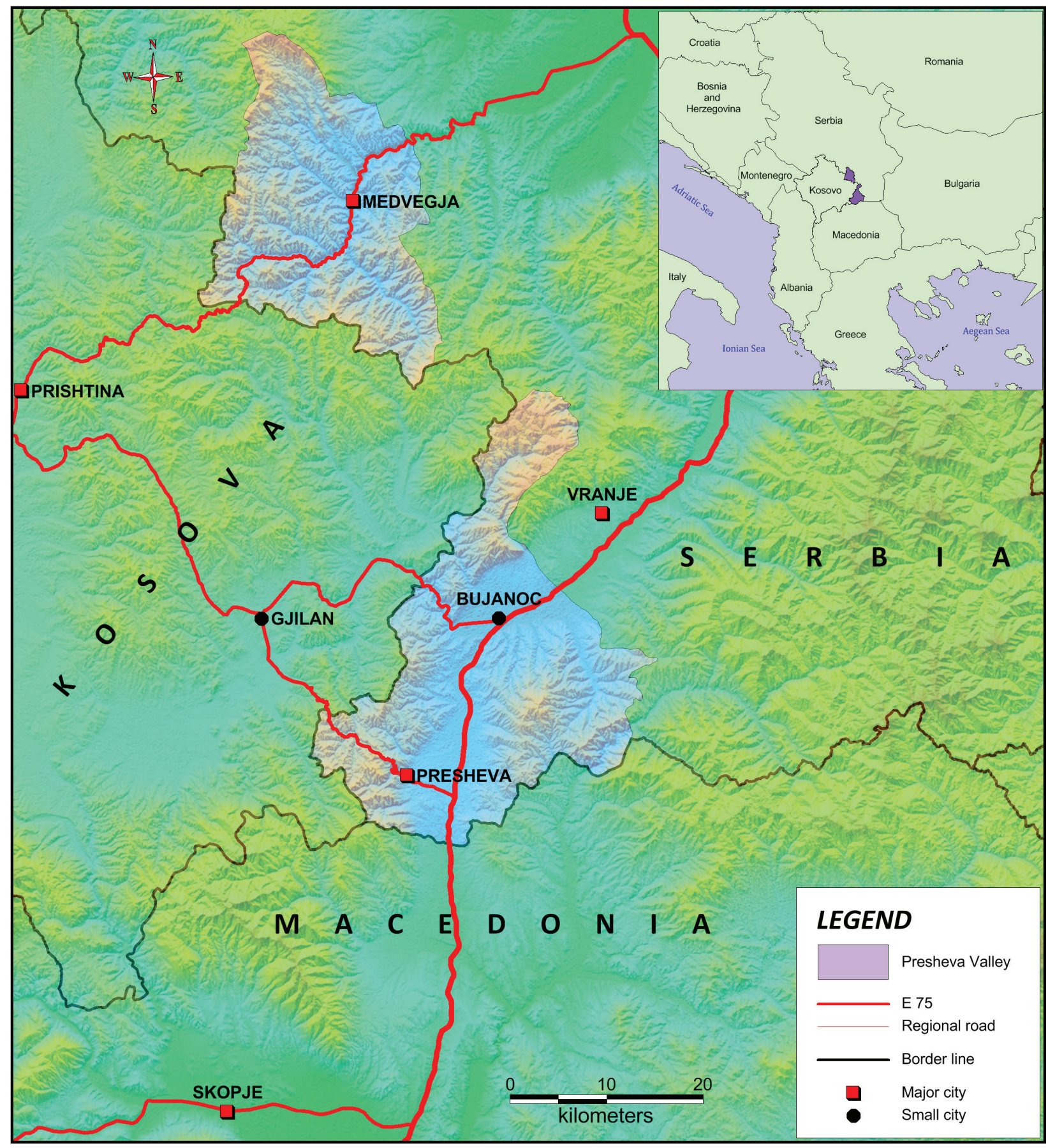

Figure 1. Geographical position of the Presheva Valley

is based on the assumption of the separation of a particular space in its entirety by the variability of the characteristics of one or more occurrences (Fuerst-Bjeliš 2007). It presents a set of methods, applied scientific practices, used for the recognition of different regional structures. From this we can understand that regionalization, in fact, represents Regional Applied Geography.

Regionalization is very important in terms of social, economic and political processes. It helps in state regulation through its particular regional organization, the social and economic regulation of the territory of the state. It helps in alleviating political, social and economic disparities between different regional sites within the state, and so on. From the initial period of development of Regional Geography as a scientific discipline until the present day, there has been a constant evolution of ideas and definitions relating to the region as a specific geographic category. In these evolving definitions, there is a change in the importance of the criteria under which regionalization is made. In the beginning, regions were usually defined by taking into account the principles of the physical determination of space. Later on, in the analyses of the internal structures of such individualized sites, it was based 
on other characteristics, such as demographic, inhabitation (population), economic-geographic, and so on.

Well-known Croatian author V. Rogić highlights the role change and the importance that physical-geographical and socio-economic factors have in the designation of the region, depending on the size of the space, which is defined in regional terms. While in most cases, the larger regional units belonging to higher levels of the hierarchy are largely determined by the main natural-geographic characteristics, in the case of smaller spatial units, social and economic factors play an important role (Rogić 1963). Over time, some progress has been made in terms of the methodological understanding that the goal of Regional Geography is primarily the separation of regions according to certain criteria, based on the principle of dominant physiognomy, functionality and homogeneity (Marković 1980).

In this brief overview, it is concluded that there are different criteria in the definition of certain spaces in regional terms, of which the following are distinguishable: the homogeneity of natural elements, social and economic factors, uniformity, perception and feeling on regional affiliation, and pragmatism.

The large number and variety of aspects under which the differentiation of territory in regions is made possible leads to the conclusion that the process of regionalization can take into account any feature that has spatial parameters. Therefore, even the method of regionalization has emerged from the classical frameworks of Regional Geography and has received the general character of the method used in all sciences that look into various aspects of the spatial relationships between phenomena (Radovanović 1994).

During the attempt to define the Presheva Valley in regional terms, we were faced with certain difficulties which resulted primarily from the fact that there is a lack of territorial continuity between the municipality of Presheva and Bujanoci and that of Medvegja, despite the certain degree of physical-geographical heterogeneity, specifically geomorphologic. The areas around Presheva constitute a special morphological unit, while the areas of Bujanoci are an integral part of the Depression of Vranje and Bujanoci. All other natural-geographic components, such as climate, water, soil, vegetation and landscape, have a high degree of homogeneity and uniformity.

Despite the low level of homogeneity of the physicalgeographical components mentioned above, the ethnodemographic, social and economic homogeneity is very high in the Presheva Valley. One of the elements that can be distinguished with a high degree of homogeneity is the population of the Presheva Valley, which fulfil the above criteria in all elements of the demographic regime, with the same birth rates, mortality and natural growth, which also have the same or a similar intensity of development. In the three municipalities of the Presheva Valley, there has until recently been a high birth rate and a falling tendency for mortality, which has resulted in very high natural growth.

Even the other structural characteristics of the population of the Presheva Valley are distinguished by a high degree of homogeneity, uniformity and consistency; the ethnic structure, with a continuing dominance of the Albanian ethnic element, should be emphasized. This important structural element is evident in the municipality of Presheva and Bujanoci. Meanwhile, there is evidence of the disruption of this intensity of development in Medvegja, due to the different ethnic composition of the population, with a smaller ethnic Albanian element in relation to Serbs and other ethnicities, and a trend towards increasing diversity caused by the decrease of the ethnic Albanian element.

In addition, other factors, such as biological, educational, linguistic, religious, social and economic, show a high degree of homogeneity and uniformity throughout the area, with the dominance of a young population, the majority of the population being of Muslim confession, high but declining literacy, especially among women, the dominance of urban over rural population, a high proportion of the agricultural population within the entire population, an extremely unfavourable ratio between the active population and the non-active population (not participating in economic life), the unaffordable structure of the active population according to sectors of activity, with the domination of the primary sector, and so on.

During the theoretical overview of the region and regionalism given above, it was emphasized that the region is also a mental construction. This mental construction is a result of the spatial perception of the population in terms of uniformity or diversity. We think that the population of the Presheva Valley region perceives it as a space of shared tradition, history, culture and identity.

Finally, we think that the Presheva Valley is an area that exists in the collective consciousness of the population, where the name (region) is connected with a sense of relatedness and affiliation which comes from a common origin, culture and history.

The geo-transportation position and geopolitical dimension of the Presheva Valley

The position in terms of transportation, as well as the strategic position, are very important elements that result from the quality of the mathematical, physical and geographical components of geographical position that have had an impact on the demographic, social, economic and geopolitical development in the historical and current context. The Presheva Valley, with its mathematical-geographical position and physical-geographical conditions, is distinguished by a very favourable geostrategic position, including transportation-wise.

Within the complex analysis of the geographical position of a territory, the geostrategic position is a relative or secondary component of its geographical position as a variable historical category. In certain circumstances, countries (or parts of them) can play an important role in defence or attack, affecting control of the sea, land or water, the protection of roads or the realization of economic ties (Grčić, 2000). The value of the geostrategic position is variable, which means it may decrease or increase during certain historical periods, depending on the geopolitical balance of forces, as well as changes in technology and types of transportation. Examples of the geostrategic factorizing of a territory or region are numerous, as are cases of decreasing the geostrategic importance of countries or territories of certain regions. The discovery of the American continent led to the displacement of geostrategic importance from the Mediterranean into the Atlantic region.

The Presheva Valley is an example of the permanency of geostrategic importance of a territory through different historical periods. According to geostrategic and geo-transportation importance, the Presheva Valley is part of the key areas, such as harbours, maritime straits and channels, which represent a 'gate' for international traffic corridors. In his work 'The basis of geology and geography of Macedonia and Old Serbia', Serbian geographer and founder of an anthropological-geographical school Jovan Cvijić (1865-1927) wrote that the Presheva Valley is known as the 'Balkan nucleus' (Cvijic 1906). According to him, 'the territories of Skopje and Presheva are of particular importance because they hold the key to transportation and are the most important longitudinal and transversal lines of transportation. Because of all these features, the territories of Skopje and Presheva may become attractive positions from which the majority of the Balkan Peninsula can easily be ruled and from where a powerful state in its interior can be developed'. Even adherents to Cvijić's theory on 'connections and interweaving' (Theory of 'prožimanja i spajanja') say that Serbia, thanks to its possession of giant geographic directresses, such as longitudinal valleys 
Table1. Ethnic structure of the population of the Presheva Valley for the period 1961-2002

\begin{tabular}{|c|c|c|c|c|c|c|c|c|c|c|}
\hline \multirow{2}{*}{ Ethnicity } & \multicolumn{2}{|c|}{1961} & \multicolumn{2}{c|}{1971} & \multicolumn{2}{c|}{1981} & \multicolumn{2}{c|}{$\mathbf{2 0 0 1}$} \\
\cline { 2 - 12 } & Number & $\%$ & Number & $\%$ & Number & $\%$ & Number & $\%$ & Number & $\%$ \\
\hline Albanians & 39,884 & 44.3 & 65,507 & 53.3 & 72,484 & 74.1 & 80,204 & 79 & 81,978 & 73 \\
\hline Serbs & 45,229 & 50.2 & 37,619 & 39.8 & 18,486 & 19 & 14,268 & 14.1 & 24,134 & 21.4 \\
\hline Roma & & & 3,113 & 3.29 & 4,056 & 4.14 & 5,032 & 4.95 & 4,306 & 3.91 \\
\hline Others & 4,933 & 5.48 & 3,395 & 3.59 & 2,830 & 2.73 & 2,045 & 2.01 & 1,791 & 1.73 \\
\hline
\end{tabular}

Source: Population census, Year 1961, Vital, ethnical and migration features, Book number VI, Belgrade, 1967; Population census, Year 1971, Ethnical features of population, Results by municipalities, Belgrade, 1974; Population census 1991, Population according to national affiliation; Population census 2002, National or ethnical affiliation of population, Book number I, Belgrade, 2003

(Morava and Vardar), as well as transversal ones, in regional constellations, has the favourable geographical prerequisites to be the most important area of Eastern Europe (Radovanović 1983).

This conclusion of Cvijić and followers of his school seems to have prevailed, since the Presheva Valley is considered a 'crucial space' in geostrategic terms, from where a strategic position in terms of the neighbouring geopolitical factors can successfully be provided. On the other hand, scientific description of these premises of the Presheva Valley in the regional context highlights the longstanding hegemonic intentions of Serbia to maintain control of the territory and dominance in the Balkan Peninsula (Sekulović 2006).

Political-geographical position represents the relationships (links) of a country or a region with the specific political factors surrounding them. According to Professor Mirko Grčić, the most important attributes of the geopolitical position of territory are potential character and historical variability. This means that the political and geographical objects and phenomena exist in the same space and vary across historical periods. In contrast to the politico-geographical position, the geopolitical position has a narrower meaning. It is focused on the impact of geographic factors in historical-political processes.

Detailed analysis of the geopolitical position components allows their classification into several categories, such as the geopolitical position of the buffer zone, the contact, the enclave, the position of the corridor (Presheva Valley), the transitional position, and so on. Although it is a secondary category or relative geographical position, the geopolitical position of a region or state represents the most conceptual and dynamic constitutive element of geographical position, covering natural, economic and politico-geographical factors. It includes the assessment of natural processes and modern realities in demographic, cultural and political terms. Basically, this position is based on the analysis of physical-geographical and anthropological-geographical factors; the causal connections between them, as well as changes in geopolitical terms for the people, the region and the state, often have direct existential consequences. It focuses on the implications of geographical factors in historical and political processes and represents an important factor which determines the development of a region or country and the possibility of its involvement in political, economic and security integrations.

The quite concise definition of the geopolitical position of a region or country indicates that there is a group of factors which determine the geopolitical position, such as physical-geographical factors, anthropological-geographical, historical, political, and so on. These factors, in the case of the Presheva Valley, favour the geopolitical position. However, in order to analyse and explain the geopolitical position of the Presheva Valley, we analysed the current political-geographical trends within the state of Serbia and its geopolitical position within the ethnic Albanian territories.
The ethnic structure of the population

The geopolitical position of the Presheva Valley in the past as well as nowadays, is sensitive primarily due to the ethnic and demographic composition, with Albanians making up the majority of the population. Official data from censuses in Serbia for the period 1961-2002 shows that the Albanian population in the Presheva Valley has steadily increased from $44.3 \%$ in 1961 to $78.8 \%$ in 1991 . It should be noted that the small percentage of Albanians in relation to the Serbs in 1961 is the result of the emigration of a considerable number of the Albanian population in Turkey and the exclusion of a significant number of the population of mountainous villages from the census, while the decline in the number of Albanians from $78.9 \%$ in 1991 to $72.9 \%$ in 2002 is the result of the application of the concept of resident population. The census of 2002 excluded about 23,743 inhabitants or $20.8 \%$ of the total population of the Presheva Valley, who live and work in other European countries. Therefore, the 2002 census gives us an incorrect picture of the ethnic structure of the population.

The dominance of the Albanian population is evident, especially in the municipality of Presheva, where Albanians make up around $94 \%$ of the overall population of the municipality in 2002 , classifying it as one of the most homogeneous municipalities in terms of ethnic composition.

\section{The transboundary position of the Presheva Valley}

Cross-border regions are usually undeveloped compared to central regions or those that are close to the centre. The social and economic backwardness of these regions should be viewed in the context of strategic objectives and security for countries with close ties to their neighbouring countries. There are a lot of geographical problems are in cross-border areas. These problems are complex and structurally diverse, with different intensity, causes, consequences and territorial expansion. The low level of economic development, isolation in terms of transportation, migration and depopulation processes, ethnic problems, undefined legal and political status, and unsustainable exploitation of natural resources are some of the problems faced by cross-border areas in the Balkan Peninsula.

This situation is inherited from past circumstances, when geopolitical boundaries were used as cut lines between countries. It should also be emphasized that this situation can be applied primarily to countries and regions with a fragile stability, post-conflict countries with a nonconsolidated democracy and numerous problems of a social and economic nature. Unfortunately, this continues to be characteristic of the Balkan

${ }^{1}$ Popis stanovništva 1961 godine, Vitalna, etnička i migraciona obeležja, Knjiga broj VI, Beograd, 1967; Popis stanovništva 1971 godine, Etnička obeležja stanovništva, rezultati po opštinama, Beograd 1974; Popis stanovništva 1991, Stanovništvo prema nacionalnoj pripadnosti; Popis stanovništva i stanova 2002 godine, Nacionalna ili etnička pripadnost, Knjiga broj I, Beograd, 2003. 
Peninsula in general, and Serbia in particular. Some Serbs think that the problems, or certain elements of the problems and their transboundary impacts, depend on political and economic factors and other neighbouring countries (llić and Sećibović 1987). According to them, these problems have changed over time, often becoming more complex. This is because, during the withdrawal of boundaries in a space that is inhabited, the borders have the function of separation, leaving inevitable consequences in terms of spatial functioning. Changing the border for a certain space means improvement for some, while for others it has a detrimental effect on spatial and functional relations. Damage to spatial-functional relations is particularly evident when the new border line divides common geo-ethnic territory and interrupts ethno-demographic continuity. Among the many examples of damage to these relations is the case of the Presheva Valley, which is distinguished by a dominance of ethnic Albanians, making its geopolitical position more sensitive.

Because of the centralist regulation of states, transboundary regions in Eastern Europe are beyond the main routes of circulation for goods, capital and information. They are peripheral in relation to the corridors and main development centres, and as such they are distinguished by low levels of economic development, low standard of living, depopulation processes, and the unused economic potential of the territory. The unfavourable position of transboundary regions is highlighted to an even greater extent by the impact of the geopolitical situation in the wider context through the beginning of various conflicts (Grčić et al 2003). This situation prevailed especially in the early 1990s, after the beginning of the dissolution of the former Yugoslavia. The ethnic mosaic, as one of the main features of the former Yugoslavia, was characteristic especially of transboundary areas, where certain ethnic communities live who are considered national minorities in municipalities where the majority group are more prevalentfor instance, Albanians in the Presheva Valley, Bulgarians in Eastern Serbia, Muslims in Sandžak, Hungarians in Vojvodina along the border with Hungary, and so on. From the early 1990s onwards, the demands of these ethnic communities to achieve their national rights in the fields of education, culture, information, and intensifying relations with their respective mother countries, were seen by Serbia as tendencies towards disintegration, the interference of neighbouring states in the internal affairs of Serbia, and separatist movements. Serbia's political stance towards nonSerb ethnic communities in transboundary areas continues to conceal the aspirations of its long-term territorial claims towards neighbouring countries like Kosovo, Bosnia and Herzegovina and Macedonia. From the perspective of integration processes in Europe, boundaries are increasingly losing the role of separation and isolation and are becoming attractive factors in cross-border cooperation, leading to the promotion of values and the overall social and economic development of these areas.

Although the Presheva Valley is situated in a triangle between Serbia, Kosovo and Macedonia, this area is characterized by a low level of cross-border cooperation between cross-border municipalities of neighbouring states, especially between Kumanova and Gjilani. The transboundary position of the Presheva Valley is an advantage and, if it is properly valorised, it could lead the municipality and the region as a whole towards a faster economic development. Therefore, one of the basic strategic orientations of the Presheva and Bujanoci municipalities should be the intensification of cross-border cooperation in the field of protection of natural resources, the realization of regional infrastructure systems, strengthening the partnership between local and municipal governments, and joint presentations for IPA funds and other financial bodies of the EU. The cross-border cooperation of municipalities implies the bilateral, trilateral and multilateral cooperation of different bodies of local and regional authorities (enterprises and institutions, including the crossborder cooperation of the private entities that are located in neighbouring geographical regions). This definition is given by the Committee of the Regions within the European Union. The Committee of the Regions and other committees and similar organizations within the EU promote and stimulate cross-border cooperation in the Balkan Peninsula. This form of cooperation promotes the relaxation of tense interethnic relations which are manifested and reflected especially in the border regions.

These attempts will give the opportunity for intergovernmental cooperation between the Western Balkan countries aspiring to become members of the European Union. This kind of cooperation can be seen in Euroregions, which represent crossborder structures that promote and stimulate local units or regional governments to cooperate with each other to achieve common interests and improve the standard of living on both sides of the border.

The main goals of cooperation within Euroregions are the cross-border harmonization of economic development programmes, the creation of a favourable environment for investments in the region, establishing communication between educational institutions and scientific research in cross-border areas, improving infrastructural connections and facilitating the free movement of people, capital and goods, promotion of the diversity of cultures and the preparation of respective regions and countries for European and Euro-Atlantic integration processes.

The Presheva Valley as a border region has moved and continues to bear the consequences of the geopolitical developments of the past that have characterized the Western Balkan region. It has played an active part in these developments, since its territory has been the scene of armed conflict which has had economic, social, political and ethno-demographic consequences for the territory.

The extreme economic backwardness of the region, isolation in terms of transportation, repression and physical violence against the population of the Valley, migration and depopulation, and the tension in interethnic relations between Albanians and Serbs, are some of the main distinguishable features of the region. In order to rehabilitate the consequences of the armed conflict on the territory of the Valley, the European Union initiated the creation of the Gjilani-Presheva-Kumanova micro-region. This idea was initiated in 2002, when a joint statement signed in Kumanova by 15 municipality mayors from Kosovo, Serbia, Macedonia and Bulgaria clearly expressed a desire and readiness to intensify political and economic cooperation. This project was designed by the East West Institute and was financially supported by the Swedish SIDA ${ }^{1}$. The first stages of the project of the Gjilani-Presheva-Kumanova micro-region, which was later joined by another municipality, Trgovište, had the objective of stimulating the political consensus at the local and state level, to find solutions to the problems faced by communities within the $\mathrm{GPKT}^{2}$ micro-region. This began in the field of civil society cooperation, to improve capacity and support cross-border multiethnic partnerships (Sherrif 2005).

Despite numerous opportunities to intensify cross-border cooperation and the implementation of various development projects in infrastructure, economy, culture, education and so on, this cooperation has remained at the level of tripartite meetings and several joint workshops, organized in Presheva, Kumanova and Gjilani. Although the GPKT micro-region is moving towards becoming a Euroregion which has among its main postulates the free movement of people, the opposite has happened in the case of the municipalities. Problems with opening the border point between the villages of Miratoci and Llojani (Macedonia) continues to be an obstacle to the free movement of people, while the government decision on the payment of vehicle insurance 


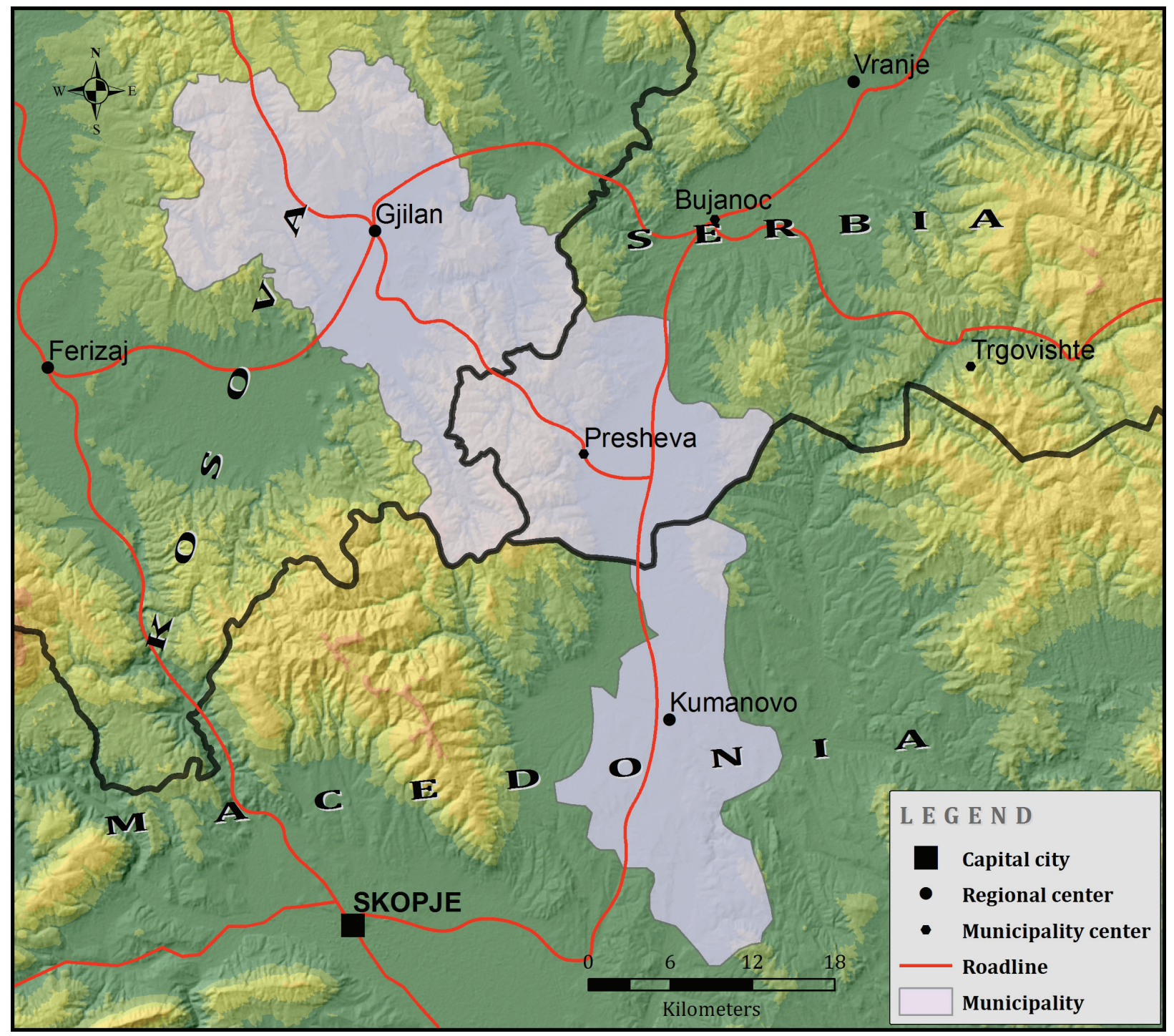

Figure 2. Transboundary municipalities in the Kosovo-Serbia-Macedonia triangle (Gjilan-Presheva-Kumanova)

has been hindering the movement of the Albanians towards Kosovo for several years. A positive step that brings a degree of convenience for the movement of people within the region is the implementation of the integrated border management between Kosovo and Serbia. Unlike the Presheva Valley, which has seen very little concrete materialization of cross-border cooperation, Kumanova and Gjilani have implemented an infrastructure project - a road which crosses through the highlands of Karadak. In addition to the transportation of two cross-border municipalities, the road through Karadak will positively influence the reduction of depopulation processes, among other things. This model of cooperation should be applied between the municipalities of Presheva, Bujanoci, Gjilani and Kamenica.

A kind of cross-border cooperation between three neighbouring municipalities can be accomplished in the field of the sustainable use of the natural resources of the Karadak Mountains. The declaration of this area as a transboundary Natural Park, similar to transboundary protected areas and transboundary peace parks, and the creation of a joint management body, can lead towards the rational and sustainable utilization of forest resources and ecosystem protection. As a result of the lack of control and presence of the relevant bodies, there is evidence of illegal wood logging and destruction of forest ecosystems, with the mountain area also being a route for the cross-border smuggling of goods and illegal trade.

Mountainous parts of Karadak can be transformed into a space that promotes the values of cooperation, which can be applied in the field of environmental protection to develop the economy, culture and education. The joint management of natural resources on all three sides of the border and the promotion of the common natural values and other ethnographic features of this area may be a positive example for the development of various forms of ecotourism. Another positive example that should be followed is the cooperation of the mountaineers' associations from the Presheva Valley, Kumanova, Gjilani and other cities that traditionally organize meetings and mountain climbing at Ostrovica Peak (1.164 m altitude), which represents a border point between Presheva, Gjilani and Kumanova. 
MISCELLANEA GEOGRAPHICA - REGIONAL STUDIES ON DEVELOPMENT

Vol. 20 • No. 4 • 2016 • pp. 22-28 • ISSN: 2084-6118 • DOI: 10.1515/mgrsd-2016-0024

\section{Conclusions}

The territory of the municipalities of Presheva, Bujanoci and Medvegja is part of a larger area, which includes the regions of Gallap and Karadak, together with the whole of Kosovo, as well as the Kumanova-Shkup/Skopje Valley and the Karadak zone, most of which is now part of the territory of Macedonia. The number of Albanians in the Valley has been decreasing dramatically, especially in the Medvegja municipality, where at some stage Albanians comprised a third, and in some parts a quarter, of the total population; nowadays there is only a symbolic presence of Albanians in this area, with only a few hundred native Albanian residents still living there.

In this overview of the Presheva Valley in different historical periods, we can conclude that the Valley has long had the characteristics of a particular region but, because of the features it shares with other parts of ethnic and demographic Albanian territories, it was separated over time for the purpose of the ethnic and linguistic assimilation of Albanians. This finding is in full compliance with the theoretical and practical principles of political geography and the numerous examples where internal borders and political organization within countries have intended to promote or prevent certain processes such as the fragmentation or integration of a space or an ethnic group. From all the above objectives in the process of the territorial organization of states, in the case of the Presheva Valley, since the Ottoman period the dominant objectives have been those aiming at isolation, interruption of ethnic continuity, economic and social backwardness, and the displacement of the Albanian population.

Serbia has tried to achieve its goals through giant infrastructure projects such as the Belgrade-Bar railway and, finally, the new (old) idea of opening the Danube-Morava-Vardar-Thessaloniki channel. Even these project ideas, like most other projects, have expected to cross through the natural part of the Albanian geoethnic territories located in the Presheva Valley.

\section{Notes}

1. Swedish International Development Agency

2. Transboundary region of Gjilani-Presheva-KumanovaTrgovište

\section{References}

Cvijić, J 1906, Osnove za geografiju i geologiju Makedonije i Stare Srbije, Beograd.

Fuerst-Bjeliš, B 2007, Principi i metodi geografske regionalizacije, Zagreb.

Grčić, M 2000, Politička Geografija, Geografski Fakultet, Beograd.

Grčić, M \&Ratkaj, I 2003, Evroregioni i evrokoridori kao faktori integracije zemalja Jugoistočne Evrope, Geografski Fakultet, Beograd.

Ilić, J \& Sećibović, R 1987, 1987, Granično područje Jugoslavije, - neke političko-geografske karakteristike i problemi, Odsek za Geografiju i Prostorno Planiranje, Prirodno Matematicki Fakultet u Beogradu i Narodni Muzej u Vranju, Vranje.

Marković, J 1980, Regionalna Geografija Jugoslavije, Građevinska Knjiga, Beograd.

Pavlović, M \& Šabić, D 2006, Regionalni pristup i tipovi regionalne diferenciajcije teritorije, Geografski Institut Jovan Cvijić, Zbornik radova, SANU, Beograd.
Radovanović, M 1994, Regionalizam kao pristup i regionalizacija kao postupak u funksionalnoj organizaciji prostora, Geografski Institut Jovan Cvijić, Zbornik radova, SANU, Beograd.

Radovanović, M 1983, Prostorne determinante i faktori demografskog razvitka u Srbiji, Statističar, Beograd.

Rogić, V 1963, 'Geografski koncept regije', Geografski Glasnik, vol. 25, pp. 113-119.

Sekulović, D 2006, Geostrateški položaj i značaj geoprostora Vranjsko-Bujanovačke kotline, Globus, Beograd.

Sherrif, A 2005, Ways forward for conflict prevention and development in GKPT, Policy brief, East West Institute, Junne. 